\title{
ICONIC BUILDINGS IN URBAN SUSTAINABILITY
}

\author{
Şengül YALÇINKAYA ${ }^{1, *}$ \\ ${ }^{1}$ Interior Architecture Department, Architectural Faculty, Karadeniz Technical University, Trabzon, Turkey
}

\begin{abstract}
Neoliberal globalization policies have led to the international mobility of capital rather than its accumulation at certain points. Architecture is actively involved in the system in which the global flow of people, money and information is intense. Cities, which are the places of capitalism, have assumed new functions and missions. With their finance, consumption and entertainment centers, cities compete with each other, resulting in large-scale and irreversible changes in urban landscapes. Based on the concept of "brand city" that has emerged lately, cities acquire artificial images to attract more and more attention. The most commonly used items to this end are iconic buildings, which reflect the urban identity and are unique in form and meaning. This raises the question of how urban sustainability and iconic buildings can coexist. The theoretical framework of this study is based on the concepts of urban sustainability, brand city and iconic buildings. The status of iconic structures in urban sustainability is evaluated through the works of famous architects. Iconic buildings are the indispensable elements of the system and are considered together with the existing values. They can, therefore, be an important tool in maintaining urban wealth. Creating original and unique designs while preserving the existing values can be a good solution to cities that look more and more alike as the years go by.
\end{abstract}

Keywords: Brand City, Iconic Building, Urban Sustainability, Reuse, Antwerp Port House

\section{INTRODUCTION}

Cities have been undergoing rapid change with globalization today. In the capitalist system, urban space is sometimes an object and sometimes a means of consumption, and this process is in constant motion. The dynamics of this process make cities look alike or different from each other. On the one hand, advances in technology and communication turn the world into a global village while, on the other hand, seeking the new and attracting capital require the branding of cities. Urban landmarks and historic areas that reflect cities' identities, experiences and cultures are also affected by these conditions. In the face of these winds of change, historic buildings should be reintroduced and reintegrated to urban life in order to preserve them and pass their values down to future generations. Although different approaches have been developed to this end, there have also emerged iconic buildings with significant images in cities.

Iconic buildings are considered effective architectural elements of the capitalist system and play an active role in transforming public space into a commodity. Novel forms are experimented on those buildings thanks to advances in software technology and construction materials [1]. With their unorthodox forms and structures, iconic buildings turn into commodities in the branding of cities and become spaces for consumption practices. This trend is becoming a global architectural language. Iconic buildings receive limited references from the physical environment in which they are located and assume a central role in the development of urban image, which, however, leads to the disappearance of the original values of cities. Iconic buildings, which are the global manifestations of different approaches, have an important place in historical textures thanks to their unique characteristics. The aim of this study is to determine the effect of iconic buildings on historical texture and to analyze the interaction of the unique characteristics of those buildings with urban identity. This study addresses the issue in question with reference to recently constructed iconic buildings and

*Corresponding Author:sengulyalcinkaya@ktu.edu.tr

Received: 25.06.2019 Published: 15.06.2020 
extensions to historic buildings. Designed to play a key role in urban branding, iconic buildings present themselves as detached from their surroundings while increasing the popularity of the historical environment in which they are located or the buildings to which they are annexed.

\section{RESEARCH DESIGN}

This study focused on five iconic buildings or extensions (Dancing House ,Kunsthaus Graz, Stedeljk Museum, Antwerp Port House, and Elbphilharmonie) recently constructed within different historical settings across the world and addressed their purpose of construction, design approach and contribution to the location, and significance of the location.

\section{ICONIC BUILDINGS IN URBAN SUSTAINABILITY}

Sustainability is broadly defined as the transfer of existing assets to future generations [12] Given the rapidly changing cities and living conditions, sustainability has become one of the most important concepts of today's world. Sustainability is a multidimensional concept including ecology, economy, social and cultural. This study discussed it with reference to cultural sustainability within the context of historical settings and buildings.

Buildings define the growth and change of cities and acquire a significant position in urban life with the qualities they possess and the physical environments they create [13]. It is important for people to notice this growth and change in order to become a society. The sustainability of buildings that are the landmarks of urban identity and play a key role in the formation of collective memory ensures the sense of belonging and commitment on the part of urban dwellers.

Sustainability is achieved by passing down signs and symbols from the past to future generations[14]. Urban stratification is ensured by the sustainment of historic properties and the preservation of modern buildings in cities. Globalization-induced consumption culture and spaces that accompany it cause destruction, transformation and standardization, resulting in the loss of urban values and historic textures. Cities, on the other hand, create fictitious images to find a place in the global system. While doing this, they ignore their authentic values and cause them to vanish over time.

Historical settings with their tangible and intangible values are important landmarks of urban sustainability. Besides their use value, they contribute to economic, social and cultural life and play a key role in the formation and preservation of urban identity and collective memory. Historic buildings either become inoperative due to changing conditions over time or unusable due to obsolescence and depreciation. At this point the question arises: How can historic buildings be reintroduced to urban life? Within the historical environment, a building can be preserved by adapting to today's conditions. Approaches to historic buildings may differ given the loss of function, obsolescence, depreciation and consumption-oriented reformulation of the whole urban space. There are different approaches adopted to re-introduce historic buildings to urban life. However, this study focused on recently constructed buildings and extensions in historical settings. The approaches adopted to build a new building or extensions in a historic setting have basically similar sensitivities.

Preservation approaches in historical settings focus on making sure that original buildings do not lose their presence vis-à-vis the new buildings and extensions to be built. Article 13 of the Venice Charter stipulates that "Additions cannot be allowed except in so far as they do not detract from the interesting parts of the building, its traditional setting, the balance of its composition and its relation with its surroundings." The historic building should not turn into an extension to the new building, on the contrary the latter should highlight the former. The extension should be in such a way that it should not damage the structure of the historic building in any way; the extension should be able to be demolished in case of any damage and allow modification independently of the historic building. The 
extension is expected to be simple and in harmony with the historic building. In some cases, harmonydefying approaches may also be adopted. However, respecting and highlighting historical data is a common attitude. A building to be built in a historic setting is expected to respect the scale and proportion of the historic fabric. The new building should be constructed using contemporary materials and technologies so that its uniqueness and originality can be emphasized [15-16-17] The size, proportion and organization of historical settings are taken into account for the construction of some new extensions and buildings, resulting in stylistic imitation. However, some other extensions and buildings are constructed in a modern and simple way and respect history by interpreting existing traces. The last one is an unorthodox approach in which the new building reflects the architectural conception of its era, regardless of or even in contrast to the existing historic texture [18] . The contrast/disparity method refers toconsciously creating contrast between design elements, such as size, proportion, color, shape, texture, material, and form in a historical texture [19] oday, there is a growing number of famous architects using the contrast approach to design and construct iconic buildings in historical settings. Conventional methods allow architects tokeep or imitate the existing historic texture, whereas the contrast approach provides them with the opportunity to incorporate contemporary architectural perspectives and conditions into historical settings and accommodate both change and sustainability [20] The approach to be adopted depends on the special conditions of the historic setting.

On the one hand, cities seek to achieve the sustainability of their historical settings, while, on the other hand, they produce new layers and accompanying meanings and spaces in the face of constant change and development. Having become important means within the capitalist system today, iconic buildings are used to create urban images and are found in historical settings as well. Iconic buildings attract global capital and help cities create images, symbols and values. They attract a great deal of attention and become popular all over the world due to the architectural approaches adopted in their construction and their famous designers such as Santiago Calatrava, Norman Foster, Zaha Hadid, Daniel Libeskind and Frank Gehry. With their unorthodox forms, their desire to be great, their ambiguous meaning and codes and their new forms and materials, iconic buildings transform their surroundings into a center of attraction. They are designed in a way that they shape and govern the artistic and cultural field of where they are situated. With their interior designs independent from their setting, iconic buildings have a very clear emphasis on "me," suggesting that there was nothing before "me" and there will be nothing after "me."

The concepts of historic setting and iconic building contain special conditions and adopt approaches that stand out for themselves. Then the question arises "What architectural understanding should be adopted when these two independent concepts try to coexist?" This study examined the contribution of iconic buildings (designed as new buildings or extensions) to the sustainability of the historical settings in which they were constructed. This study evaluated the contribution of five iconic buildings(Dancing House,Kunsthaus Graz, Stedeljk Museum, Antwerp Port House, and Elbphilharmonie) to the sustainability of historical settings in which they were constructed. Tables 1 , $2,3,4$, and 5 present the purpose of construction and design approach of five iconic buildings and their contribution to the location, and significance of the location in order to determine their effect on the historical settings in which they were constructed.The study then made a general assessment with reference to those buildings. 
Table1. Evaluation of Dancing House

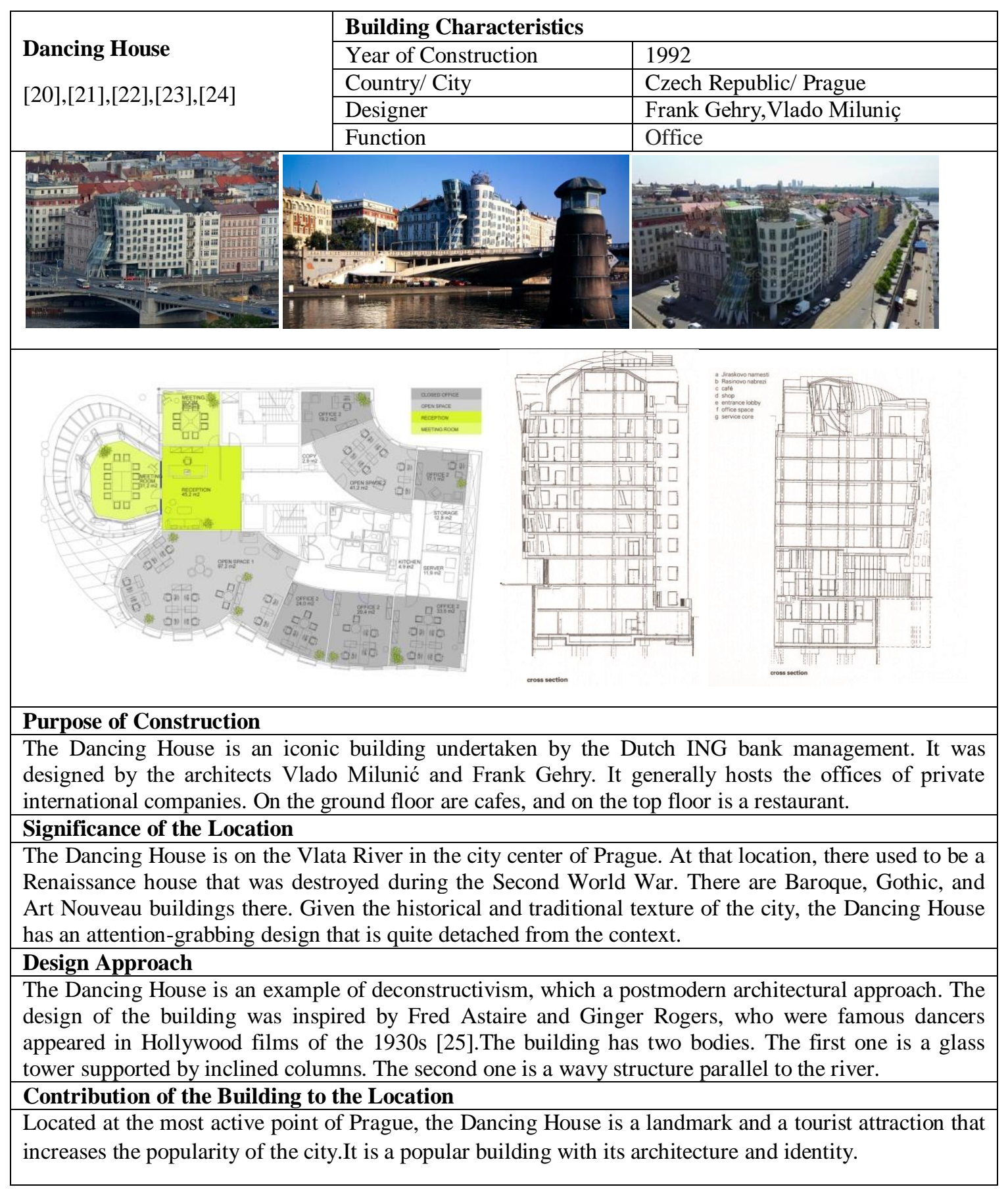


Table 2. Evaluation of Kunsthaus Graz

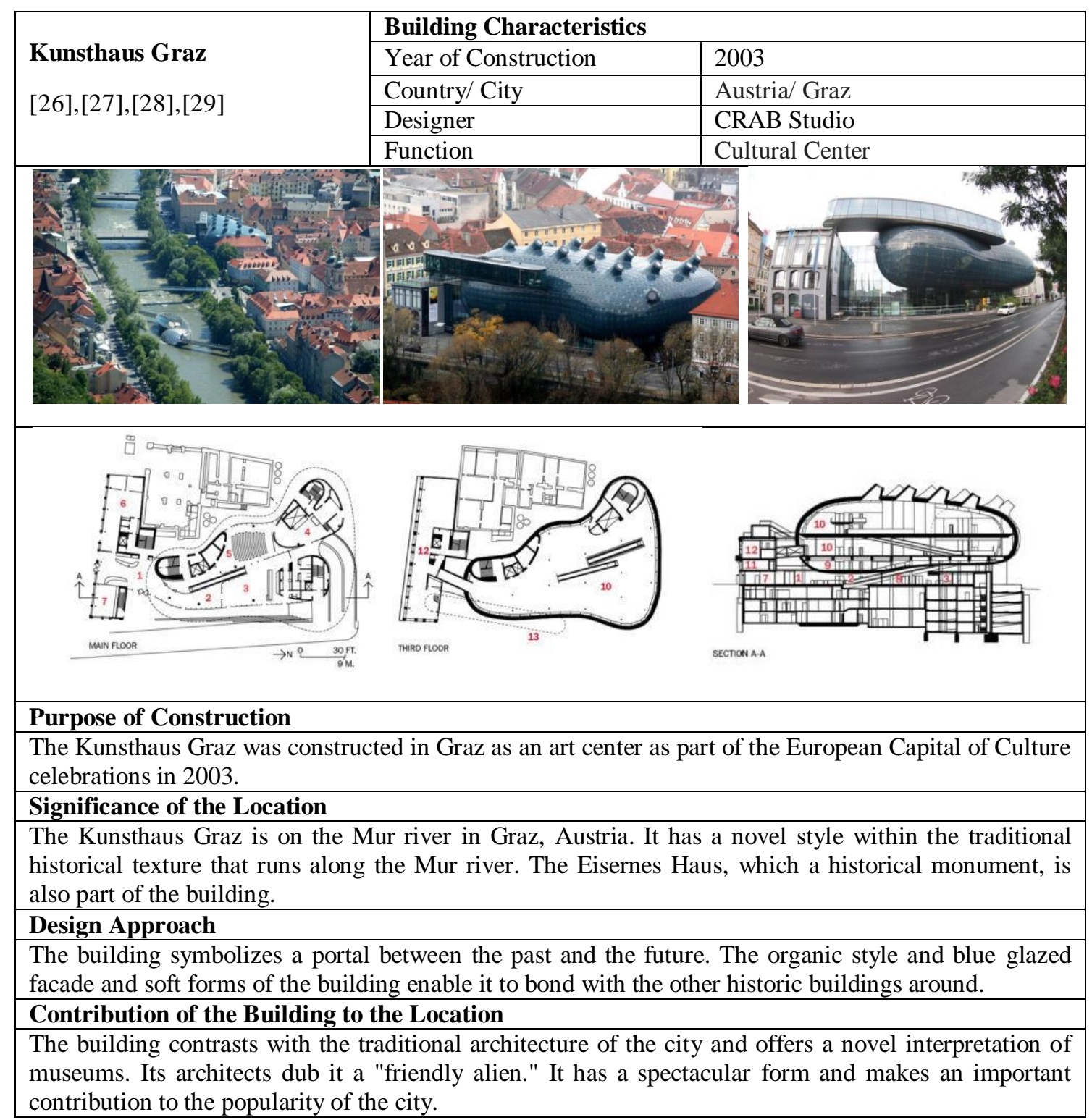


Table 3. Evaluation of Stedeljk Museum

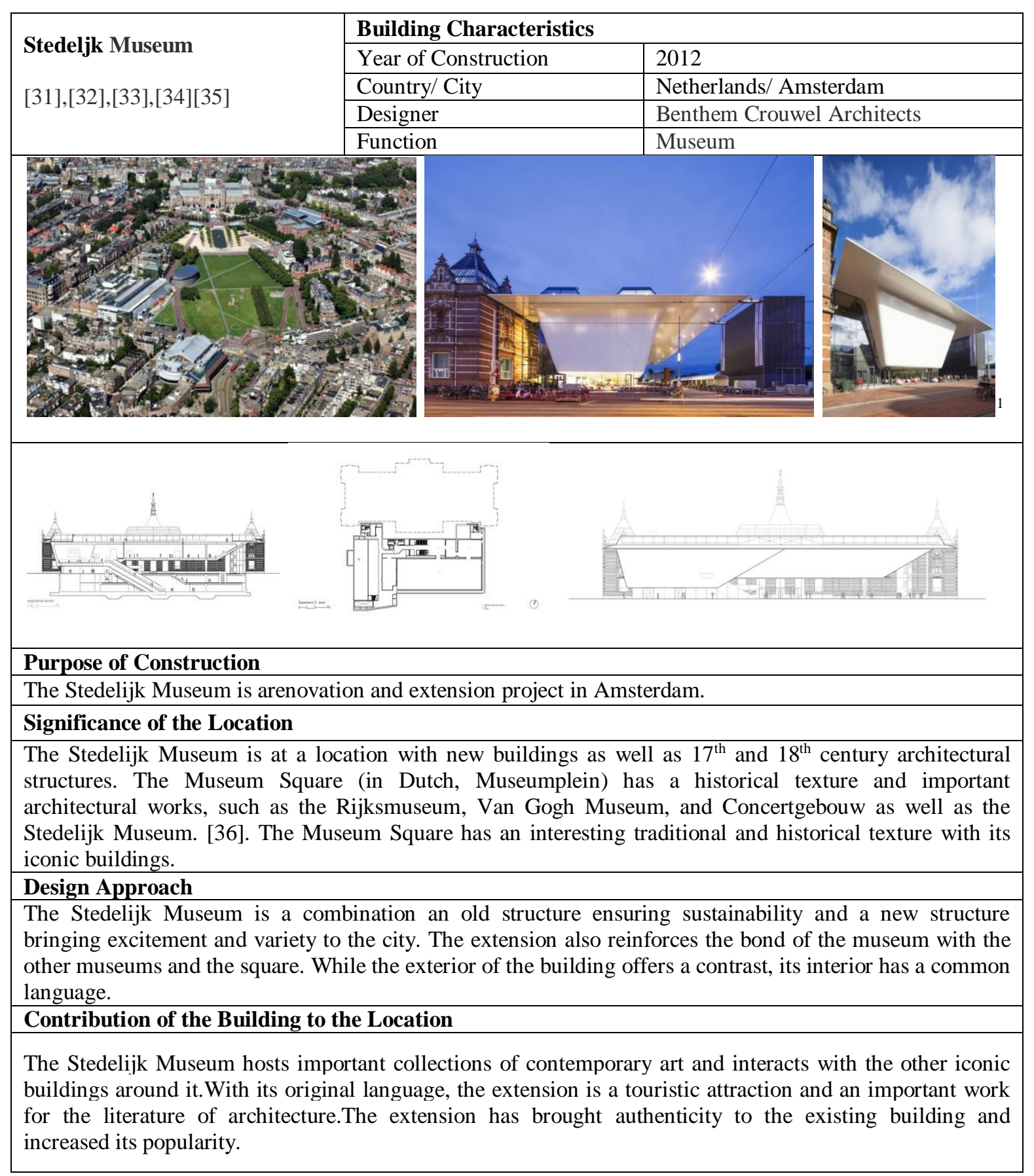


Table 4. Evaluation of Antwerp Port House

\begin{tabular}{|l|l|l|}
\hline \multirow{4}{*}{ Antwerp Port House [37] } & \multicolumn{3}{|l|}{ Building Characteristics } \\
\cline { 2 - 3 } & Year of Construction & 2016 \\
\cline { 2 - 3 } & Country/ City & Belgium/Antwerp \\
\hline & Designer & Zaha Hadid Patrik Schumacher \\
\cline { 2 - 3 } & Function & Office \\
\hline \multirow{2}{*}{} & \\
\hline
\end{tabular}

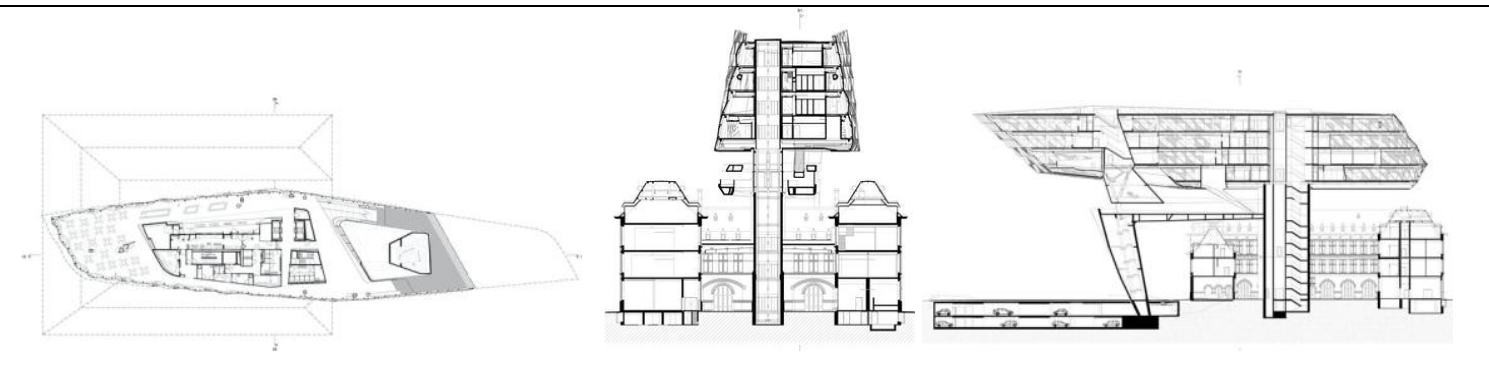

\section{Purpose of Construction}

The Antwerp Port House is a project of transforming a former Hanseatic fire station from 1922 into a new government building.

\section{Significance of the Location}

The Port of Antwerp, which is located in one of the oldest cities of Europe, Antwerp, is the second largest port in Europe and the fourth in the world. It is a trade center that dates back to the sixteenth and seventeenth centuries. The new Antwerp Port House is a project of a new government building including a historic fire station in the port.

\section{Design Approach}

It is designed as a sustainable building that represents the port in the international arena, reflects the corporate identity, and meets the needs of today and the future [38]. The new extension has completely different characteristics from the existing historical building in terms of form, shape, scale, and material.

\section{Contribution of the Building to the Location}

It is an iconic building designed using a contrast approach. Its design focuses on combining the old and the new, showing the power of the port as a global actor, and exposing its novel and bold side. It has most of the characteristics sought in an iconic building and is an important contribution to the literature of architecture. The Antwerp Port House attracts great attention not only with its striking design but also with its planning that allows visitors to view the spectacular view. Already attracting the attention of Antwerpers, the building is open to visitors on certain days and is included in tour programs. Zaha Hadid's design has increased the worldwide popularity of the historic building and the port in many areas, such as architecture and tourism. 
Yalçınkaya / Eskişehir Technical Univ. J. of Sci. and Tech. A-Appl. Sci. and Eng. 21 (2)-2020

Table5. Evaluation of Elbphilharmonie

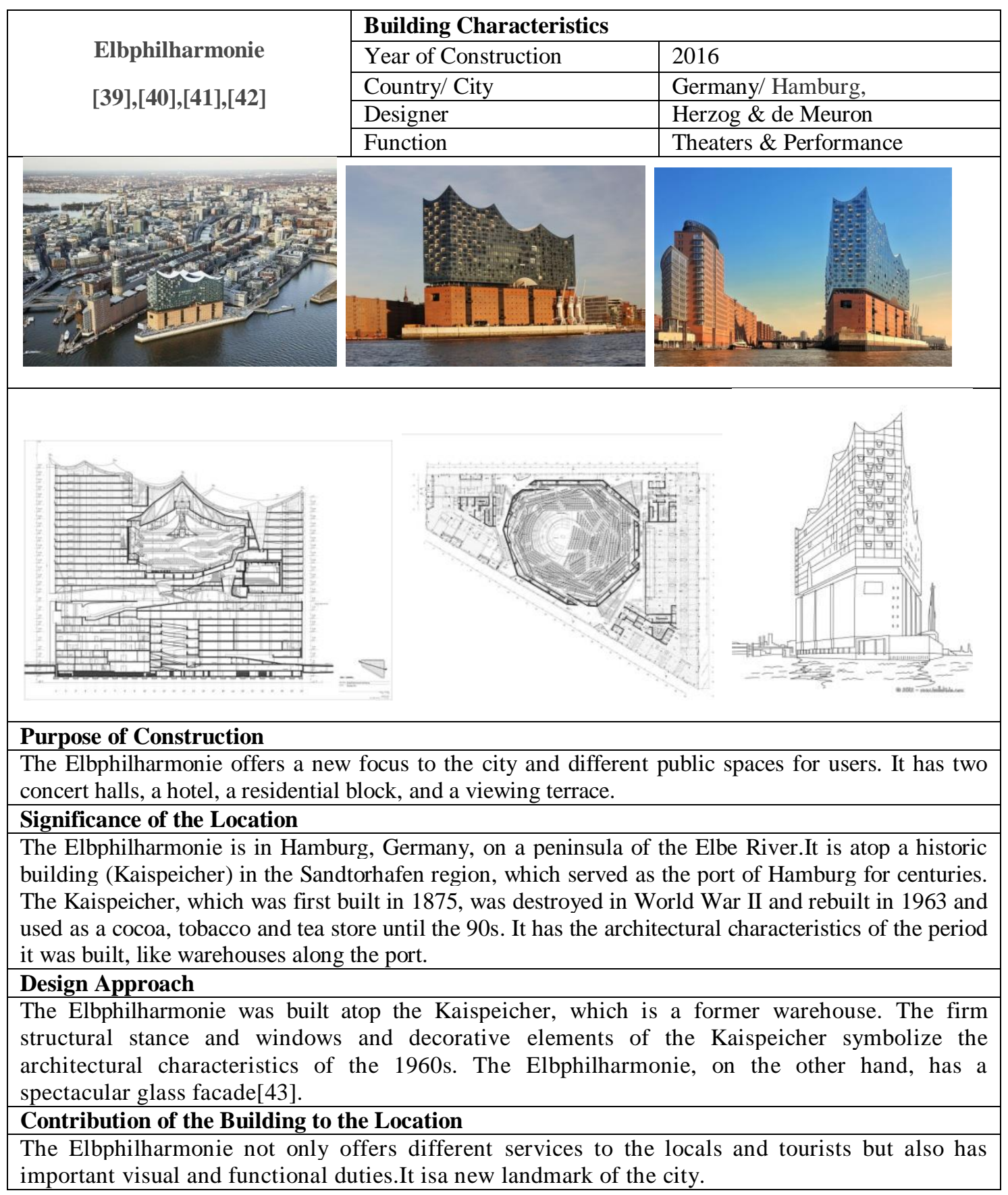

The evaluation of the five iconic buildings, whose harmony with the historical texture is based on four criteria (Tables 1, 2, 3, 4, and 5) is as follows:

- The iconic buildings (new extensions or buildings) do not reflect the scale, environment, form, rhythm and effect of the material of historical settings. They are detached from the identity and silhouette of the historical texture.

- The iconic buildings focus on contrast, and therefore, are detached from surroundings and contexts. They put themselves at the forefront and overshadow the original historic buildings. 
- Although the iconic buildings reflect the materials, architectural conception and technologies of the era they were built in, they fail to provide strong urban sustainability.

- The iconic buildings are designed to create a brand, independent of geographical, historical and socio-cultural life, and therefore, they draw attention to the historical environments or structures in which they are located and increase their popularity.

- Although the iconic buildings benefit from some of the design features of the existing texture, they often adopt different approaches in terms of design elements.

- With their geometric forms and unusual compositions, the iconic buildings attract more attention than the original buildings and create a new image for the historical setting. The combination of the new and old buildings while maintaining their originality allows for a different experience and an impressive view.

- The iconic buildings offer effective solutions for sustainability; from preservation of physical space to meeting the needs of today.They also ensure that the historical settings in which they were constructed continue to play an active role in urban life.

\section{CONCLUSION}

This study addressed iconic buildings constructed as new buildings or extensions in historical settings and analyzed the relationship between them in the context of urban sustainability. Preserving a historical setting physically is not always enough to ensure itssustainability. Repurposing, or building a new structure or an extension might sometimes be necessary. A building can be sustainable only if it can actively participate in everyday life and if people keep the historic setting in which it is built alive. Therefore, new buildings and extensions constructed in historical settings play an important role in the sustainability of existing textures. Given the loss of functionality and physical obsolescence and widespread deconstruction in cities, the reintroduction and refunctionalization of historic buildings and historical settings are of paramount importance.

Iconic buildings not only bring new images and values to urban space but also pass them to future generations. The integrity of historical settings with new buildings or extensions ensures sustainability. However, what guarantees sustainability is not only the preservation of historical settings but also the harmony between the new and old. At this point, new buildings have a great responsibility. Solutions that preserve the meaning and significance of historic buildings help achieve sustainability. To understand and evaluate historic buildings, their forms, textures, materials, scales, relationship with cities and economic factors should be taken into account. The contrast between new and old buildings helps us perceive and appreciate both eras. However, it should be made sure that historic buildings are not damaged during this process and that new buildings have unique characteristics. Satisfying these criteria allows new buildings to increase the value and strength of settings in which they are built.

\section{REFERENCES}

[1] Hasol D. Mimarlık Denince..., Yem Publications, İstanbul, 2019, 73

[2] Dancing House, [cited 201929 March]; Available from: https://www.arkitektuel.com/ danseden-ev/

[3] Kunsthaus Graz, [cited 201929 March]; Available from: https://www.arkitektuel.com/ kunsthaus-graz/

[4] Jewish Museum, [cited 201929 March]; Available from: https://www.berlin.de/en/museums/ 3108776- 3104050 -juedisches -museum-berlin.en.html 
Yalçınkaya / Eskişehir Technical Univ. J. of Sci. and Tech. A - Appl. Sci. and Eng. 21 (2) - 2020

[5] Stedeljk Museum, [cited 201929 March]; Available from: https://www.archdaily.com/ 350843/stedelijk-museum-amsterdam-benthem-crouwel-architects

[6] Sharp Centre, [cited 201929 March]; Available from: https://arcspace.com/feature/sharp-centrefor-design/

[7] Antwerp Port House, [cited 201929 March]; Available from: https://www.archdaily.com/795832 /antwerp-port-house-zaha-hadid-architects

[8] Military History Museum, [cited 201929 March]; Available from: http://www.arkitera.com/haber/3883/libeskindin-cam-bolmesi-dresden-askeri-muzesini-delipgeciyor

[9] Elbphilharmonie, [cited 201929 March]; Available from: https://www.hamburg-news.hamburg/ en/conventions -events/record-visitors-international-music-festival-thank/

[10] Royal Ontario Museum, [cited 201929 March]; Available from: https://commons.wikimedia.org /wiki/File:Royal_Ontario_Museum2.jpg

[11] Hearst Tower, [cited 201929 March]; Available from: https://www.alamy.com/stock-photo-thehearst-tower-in-new-york-city-with-its-1928-base-by-joseph-urban-97724471.html

[12] Özdoğan N.O. Sürdürülebilir turizm ve kültürel miras, M. Kozak (Ed.) Sürdürülebilir Turizm Kavram- Uygulamalar, Ankara: Detay Publications. 2014, 47-60

[13] Madran E. Kent Belleğinin Oluşumunda Mimarlık Yapıtları. Mimarlık Dergisi, 298, 2001, 47-49.

[14] Tekeli İ. Bir Kentin Kimliği Üzerine Düşünceler, Kent Planlaması Konuşmaları. Ankara: TMMOB Publications, 1991.

[15] Zeren TM, Tarihi Çevrede Yeni Ek ve Yeni Yapı Olgusu, Yalın Publications, İstanbul, 31, 2010,

[16] Kuban D. Tarihi Çevre Korumanın Mimarlık Bölümü, Yem Publications, İstanbul, 2000, 119

[17] Madran E. ve Özgönül, Kültürel ve Doğal Değerlerin Korunması, Mimarlar Odası, İstanbul, 2011, 161

[18] Zeren TM. Tarihi Çevrede Yeni Ek ve Yeni Yapı Olgusu, Yalın Publications, İstanbul, 2010, 68

[19] Kı1ıç A. Tarihi Çevrede Yeni Yapı-Yeni Ek Bağlamında Norman Foster Yapıları, Yüksek Lisans Tezi Erciyes Üniversitesi Fen Bilimleri Enstitüsü, 2015, Kayseri.

[20] Yalçınkaya,Ş, Açıcı Kurak F. ve Büyükçam FS. (2019) Tarihi Çevrede Yeni Yapi Tasarimi ve Daniel Libeskind, INTERNATIONAL BLACK SEA COASTLINE COUNTRIES SYMPOSIUM - 2, Samsun, 20-22 July, 189-200

[21] Dancing House, [cited 201929 March]; Available from: https://www.arkitektuel.com/dans-edenev/

[22] Dancing House, [cited 202020 May]; Available from: https://tr.wikipedia.org/wiki/ Dosya: Praha_Tancici_dum.jpg 
Yalçınkaya / Eskişehir Technical Univ. J. of Sci. and Tech. A - Appl. Sci. and Eng. 21 (2) - 2020

[23] Dancing House, [cited 202020 May]; Available from: https://tr.wikipedia.org/wiki/Dans Eden Ev\# /media /Dosya: Tancici_d\%C5\%AFm.jpg

[24] Dancing House, [cited 202020 May]; Available from:https://visuallexicon.wordpress.com/ 2017/10/10/the-dancing-house-vlado-milunic-frank-gehry/

[25] Çevik N, Bingöl M \& Durmuş T. Kamusal Alan Bağlamında Kentsel Mekânlarda Çağdaş Sanat Yansimalar. Fine Arts, 14(4), 284-297.

[26] Kunsthaus Graz,[cited 202020 May]; Available from:https://erasmusu.com/tr/erasmusgraz/erasmus-deneyimler/ananin-avusturya-graz-deneyimi-520837

[27]Kunsthaus Graz, [cited 201929 March]; Available from: https://www.arkitektuel.com/kunsthausgrazl

[28] Kunsthaus Graz,[cited 202020 May]; Available from: https://www.kilsanblog.com/mimarlikfarkli-ilginc-yapilar/kunsthaus-graz/

[29] Kunsthaus Graz,[cited 202020 May]; Available from:https://www.arkitektuel.com/kunsthausgrazl

[30] Kunsthaus Graz,[cited 202020 May]; Available from: https://www.kilsanblog.com/mimarlikfarkli-ilginc-yapilar/kunsthaus-graz/

[31] Stedeljk Museum[cited 202020 May]; Available from: http://www.amsterdamsights.com/ amsterdam / museumplein.html

[32] Stedeljk Museum [cited 202020 May]; Available from: https://www.arkitera.com/proje/the-newstedelijk-museum-amsterdam/

[33] Stedeljk Museum[cited $2020 \quad 20$ May]; Available from: https://www.aa13.fr/architecture/stedelijk-museum-amsterdam-benthem-crouwel-architects$\underline{17572}$

[34] Stedeljk Museum [cited 202020 May]; Available from: https://arcspace.com/feature/new-stedelijkmuseum/

[35] Stedeljk Museum [cited 2020 20 May]; Available from: https://www.theplan.it/eng/webzine/international-architecture/stedelijk-museum

[36] Öztürk DS. Tasallut Teamüle Karşı: Amsterdam Stedelijk Müzesi, YAPI Dergisi 432 Kasım, 2019.

[37] Port House, [cited 201929 March]; Available from: https://archinect.com/news/article/149970286/closer-look-zaha-hadid-s-new-floating-port-housein-antwerp

[38] Zaha Hadid Architects (ZHA), The New Port House in Antwerp, Trans. Sercan Altan, Yap1 dergisi, 422, Ocak, İstanbul, 2017, 70-71.

[39] Elbphilharmonie[cited 202020 May]; Available from: https://www.arkitektuel.com/elbphilharm onie-hamburg/ 
Yalçınkaya / Eskişehir Technical Univ. J. of Sci. and Tech. A - Appl. Sci. and Eng. 21 (2) - 2020

[40] Elbphilharmonie[cited 202020 May]; Available from: https://www.sika.com/en/referenceprojects/elbphilharmonie-concert-hall.html

[41] Elbphilharmonie[cited 202020 May]; Available from: https://www.arch2o.com/elbphilhar monie -herzog-de-meuron/

[42] Elbphilharmonie [cited 202020 May]; Available from: https://tr.pinterest.com/pin/ 4761149 91847855083/

[43] Elbphilharmonie Hamburg [cited 202020 May]; Available from: https://www.arkitektuel.com/ elbphilharmonie-hamburg/ 